\title{
Unilateral external ophthalmoplegia in Miller Fisher syndrome:
}

\section{case report}

\author{
Jonathan Smith*, Lucy Clarke, Philip Severn and Robert Boyce
}

Address: Sunderland Eye Infirmary, Sunderland, Queen Alexandra Road, Sunderland, SR2 9HP, UK

Email: Jonathan Smith* - JSMITH23@doctors.org.uk; Lucy Clarke - lucyclarke@doctors.org.uk; Philip Severn - pssevern@hotmail.com;

Robert Boyce - Robert.Boyce@chs.northy.nhs.uk

* Corresponding author

Published: 17 April 2007

BMC Ophthalmology 2007, 7:7 doi:10.1 186/147|-2415-7-7

This article is available from: http://www.biomedcentral.com/I47/-24I5/7/7

(C) 2007 Smith et al; licensee BioMed Central Ltd.

This is an Open Access article distributed under the terms of the Creative Commons Attribution License (http://creativecommons.org/licenses/by/2.0), which permits unrestricted use, distribution, and reproduction in any medium, provided the original work is properly cited.
Received: 13 November 2006

Accepted: 17 April 2007

\begin{abstract}
Background: A description of the diagnostic features of Miller Fisher syndrome.

Case presentation: The clinical presentation, investigation, and subsequent progress of our patient with clinical unilateral external ophthalmoplegia.

Conclusion: Our case demonstrates the presentation of clinical unilateral external ophthalmoplegia as part of the full triad of Miller Fisher syndrome.
\end{abstract}

\section{Background}

Miller Fisher syndrome was originally described in 1956 as a triad of total external ophthalmoplegia, ataxia and loss of tendon reflexes [1]. Since the original description acute phase immunoglobulin $\mathrm{G}$ (IgG) antibodies to GQ1b ganglioside have been recognised as a serum marker for Miller Fisher syndrome [2]. Anti GQ1b IgG antibodies are found in over $90 \%$ of cases of Miller Fisher syndrome and are highly disease specific [3]. We report a case of a 32-year old gentleman with clinical unilateral external ophthalmoplegia in Miller Fisher syndrome confirmed by positive GQ1b antibody titre.

\section{Case presentation}

A 32-year old gentleman presented to the ophthalmic accident and emergency department with a four-day history of worsening horizontal and vertical diplopia. He denied any other ophthalmic or neurological symptoms at presentation. Other than a recent mild coryzal illness he was fit and well. He had no significant past ocular or medical history and took no regular medications.
Ocular examination within the accident and emergency department showed a one-millimetre ptosis of the left upper lid, with limitation of left ocular movements in all directions of gaze. Right ocular movements were full. The remainder of the ocular and cranial nerve examination was normal. Eye movement testing showed a $-2 /-3$ reduction in left ocular movements in all directions of gaze, with an associated +2 over-action in the corresponding right ocular movements. Figure 1 shows the Hess chart recorded at presentation.

A CT scan of his head with contrast showed no abnormality and the patient was transferred to the regional neurosciences centre for further investigation where the patient was found to be ataxic on heel to toe walk and the deep tendon reflexes were absent. Further investigation including an MRI, serology, lumbar puncture and Tensilon test were normal. Anti GQ1b IgG antibodies were positive with a significant titre by laboratory reference range, confirming the clinical diagnosis of Miller Fisher syndrome. With conservative management the patient's signs and 

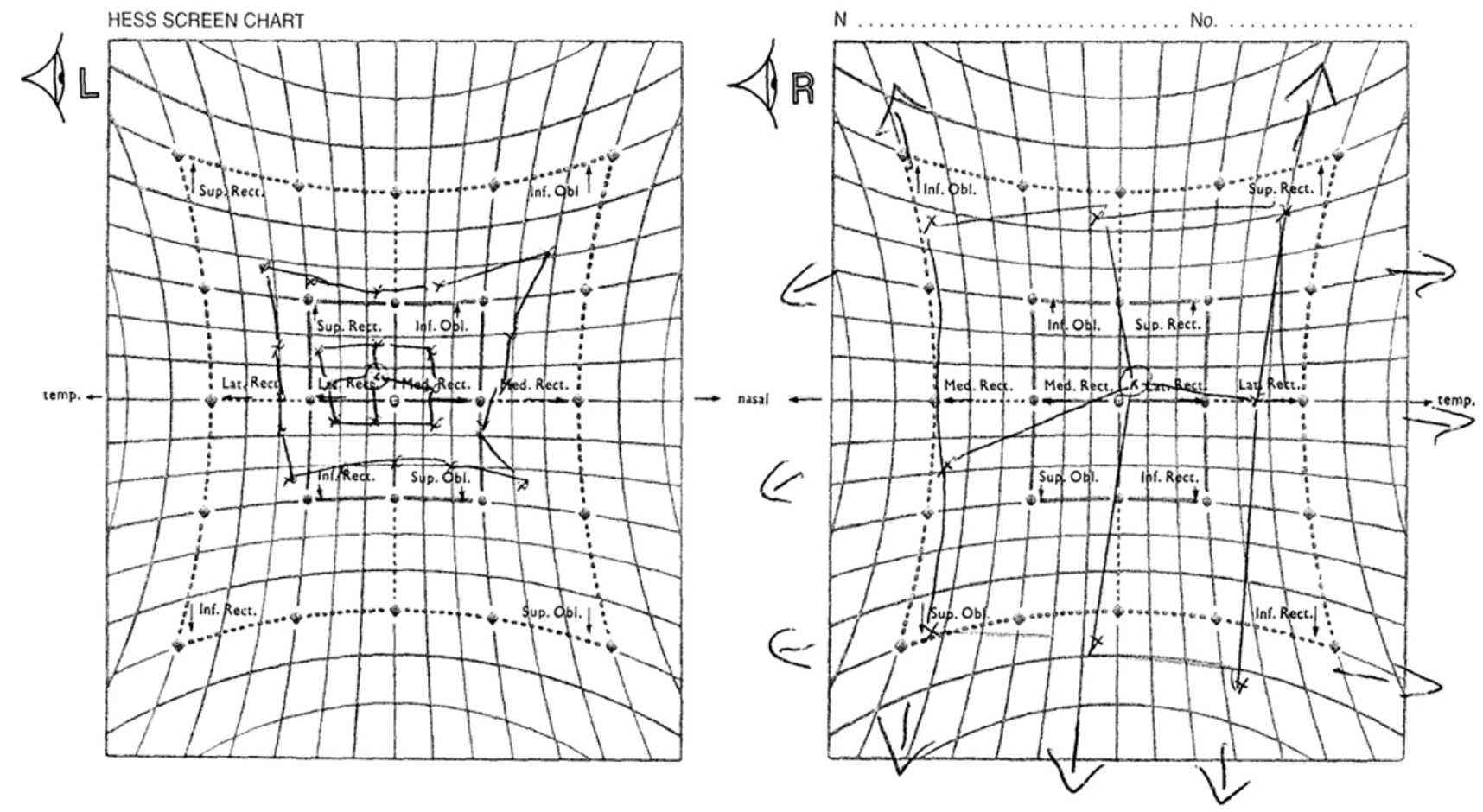

Figure I

Hess chart recorded at presentation.

symptoms resolved spontaneously within five weeks of presentation, leaving no permanent sequelae.

\section{Conclusion}

The marked asymmetry of the ophthalmoplegia in this case is unusual, and to our knowledge only a single previous report of a clinical unilateral external ophthalmoplegia as part of the full triad of Miller Fisher syndrome has been documented within the literature [4]. Acute partial bilateral and unilateral ophthalmoparesis has been documented in association with anti GQ1b IgG antibodies, however these patients were not ataxic and the presence of deep tendon reflexes were variable [5], or neurological examination was normal [6].

This case demonstrates that uniocular external ophthalmoplegia can occur as part of the full triad in Miller Fisher syndrome. This reinforces the importance of considering systemic autoimmune diseases normally associated with bilateral ophthalmoparesis, in the differential diagnosis of a patient presenting with apparently unilateral signs.

\section{Competing interests}

The author(s) declare that they have no competing interests.

\section{Authors' contributions}

JS and LC drafted and referenced the case study.

PS and RB revised the manuscript.

All authors read and approved the final manuscript.

\section{References}

I. Fisher M: An unusual variant of Acute Idiopathic Polyneuritis (Syndrome of Ophthalmoplegia, Ataxia and Areflexia). N Engl J Med 1956, 255:57-65.

2. Chiba A, Kusunoki S, Shimizu T, Kanazawa I: Serum IgG antibody to Ganglioside GQ I b is a possible marker of Miller Fisher syndrome. Ann Neurol 1992, 31 1:677-679.

3. Willison HJ, O'Hanlon GM: The Immunopathogenesis of Miller Fisher syndrome. Journal of Neuroimmunology 1999, 100(I-2):3-12.

Publish with Bio Med Central and every scientist can read your work free of charge

"BioMed Central will be the most significant development for disseminating the results of biomedical research in our lifetime. "

Sir Paul Nurse, Cancer Research UK

Your research papers will be:

- available free of charge to the entire biomedical community

- peer reviewed and published immediately upon acceptance

- cited in PubMed and archived on PubMed Central

- yours - you keep the copyright
BioMedcentral 
4. Susuki K, Yuki N, Muramatsu M, Hirata K: Unilateral ophthalmoparesis and limb ataxia associated with anti-GQ Ib IgG antibody. J Neurol 2000, 247:652-653.

5. Yuki N, Odaka M, Hirata K: Acute ophthalmoparesis (without ataxia) associated with anti-GQ Ib IgG antibody: clinical features. Ophthalmology 200I, I 08(I): I96-200.

6. Ichikawa $H$, Kamiya $Y$, Susuki K, Susuki M, Yuli N, Kawamura M: Unilateral oculomotor nerve palsy associated with anti-GQIb IgG antibody. Neurology 2002, 59:957.

\section{Pre-publication history}

The pre-publication history for this paper can be accessed here:

http://www.biomedcentral.com/1471-2415/7/7/prepub

Publish with Bio Med Central and every scientist can read your work free of charge

"BioMed Central will be the most significant development for disseminating the results of biomedical research in our lifetime. "

Sir Paul Nurse, Cancer Research UK

Your research papers will be:

- available free of charge to the entire biomedical community

- peer reviewed and published immediately upon acceptance

- cited in PubMed and archived on PubMed Central

- yours - you keep the copyright 